\title{
Modern Çă̆ Toplumlarının Geleneksel Sosyal Statüleri, Yeni Doğan Ekonomik Sınıfları ile Modern Çağın Ekonomik Kurumları, Yeni Sosyal ve Ekonomik Düzeni
}

\author{
The Traditional Social Status of Modern Age Societies, Economic Institutions with \\ New-born Economic Classes and The New Social and Economic Orders of Modern \\ Age
}

\author{
Dr. Öğr. Üyesi Enver GÜNAY ${ }^{(D)} 1$
}

\begin{abstract}
$\ddot{O} z$
Tarımın gerilediği dönemin sonunda ticaretin yükselişi ile, batı Avrupa toplumunun sosyal yapısı, ekonomik ilişkileri ve ekonomik kurumları değişmeye başladı. Eski dünyanın doğuştan gelen geleneksel statüleri ile dönemin özelliğine göre şekillenen kurumları güç kaybederek varlıklarını sürdürürken, yeni dünyanın ekonomik tabana dayanan sınıfları güçlenerek varlıklarını gösterdiler. Eski dünyanın feodal devletleri soylu ve ruhban sınıfiyla dayanışma içindeydi ve temel haklardan yoksun büyük bir çoğunluğa hükmediyorlardı. Yeni dünyanın Monarşik devletleri, tüccarlarla dayanışma içindeydiler, Monarşik devletler ve tüccar ittifakı, Orta Çăg'a nispeten daha geniş haklara sahip sosyal çoğunluğa hükmettiler. Yeni çağın ekonomik kurumları devletin ve ulusun çıkarları ile tüccarın beklentileri doğrultusunda şekillendi. Uluslararası ticaretten yalnızca bir tarafın kazançlı çıkacağı felsefesi, müdahaleci devlet karakterine, sömürgeciliğe ve imtiyazlı tüccar sınıfına uygundu. Bu çalışmada, güç kaybederek varlığını sürdüren geleneksel statüler ve kurumlar ile coğrafi keşifler ile büyüyen uluslararası ticaret ve sömürgecilikten beslenen yeni ekonomik sınıflar ve yeni ekonomik kurumların gösterdiği gelişme ve batı Avrupa tarihinin en devrimci sınıfı tüccar kapitalist sınıfın yükselişinin nedenleri ile devletçi kapitalizmin kazandığı toplumsal destekle şekillenen yeni ekonomik ve sosyal düzen incelenmiştir.
\end{abstract}

Anahtar Kelimeler: Sosyal statü, ekonomik sınıf, modern çă̆, ekonomik kurumlar

Makale Türü: Derleme

\begin{abstract}
At the end of the decline of agriculture, with the rise of trade, the social structure, economic relations and economic institutions of Western European society began to change. While the institutions of the old world, which were shaped according to the characteristics of the period with their innate traditional status, continued their existence by losing their power, the classes of the new world strengthened and showed their existence. The feudal states of the old world were in solidarity with the noble and clergy and ruled the vast majority without fundamental rights. The Monarchic states of the new world were in solidarity with the merchants; the monarchic states and the merchant alliance dominated the social majority with broader rights relative to the Middle Ages. The economic institutions of the new age were shaped in line with the interests of the state and the nation and the expectations of the merchant. The philosophy that only one side would benefit from international trade was consistent with the character of the interventionist state, colonialism, and the privileged merchant class. In this study, those, traditional statutes and institutions that continued to exist by losing their strength, new economic classes nurtured by international trade and colonialism growing through geographical discoveries, development of new economic institutions, the causes of the rising of the merchant capitalist class, the most revolutionary class in Western European history and the new economic and social order shaped by the social support that statist capitalism gained, are examined.
\end{abstract}

${ }^{1}$ Kahramanmaraş Sütçü İmam Üniversitesi, İktisadi ve İdari Bilimler Fakültesi, envergunay@ hotmail.com.

Atıf için (to cite): Günay, E. (2020). Modern çağ toplumlarının geleneksel sosyal statüleri, yeni doğan ekonomik sınıfları ile modern çağın ekonomik kurumları, yeni sosyal ve ekonomik düzeni. Afyon Kocatepe Üniversitesi Sosyal Bilimler Dergisi, 22(3), 827-840. 
Keywords: Social status, economic class, modern age, economic institutions

Paper Type: Review

Giriş

Modern Çağ 1453 İstanbul'un fethiyle başlayan ve 1789 Fransız İhtilali'ne kadar süren bir tarihi evredir. Orta Çağda Feodal prenslikleri merkezi krallıklara karşı koruyan surların, İstanbul'un fethinde, toplarla yıkılmasından sonra, derebeylikler kralların tehditlerine açık hale geldi. Feodal prenslikler yıkıldıkça, Modern Çağ'ın siyasal modeli, Monarşiler (merkezi krallıklar) güçlenmeye başladı. Modern Çağın ticari devrimi Avrupa'nın bu siyasal gelişmelerini destekledi ve Modern Çağ ticaretin dönüştürücü gücü sayesinde yeniden şekillendi. Bu yeniçağda eski dünyanın kurumları yıkılarak, yenidünyanın müesseseleri kuruldu ve Batı Avrupa toplumları siyasal, sosyal ve ekonomik değişim geçirdi. Bu değişimin öncü sınıfı, tüccar kapitalist sınıf olduğundan Modern Çağın geçirdiği değişimi burjuva devrimi olarak da görmek mümkündür. Batı Avrupa; coğrafi keşiflerden faydalanarak 15.yy.dan sonra tartışmasız bir biçimde dünyanın en hızlı gelişen bölgesi olmuş, dünya ekonomisi üzerinde 20.yüzyıla kadar hissedilecek hegemonya kurmuş, ticaret ya da sömürgecilik yoluyla, dünyanın zenginliğini Avrupa'ya taşıyacak avantaj kazanmıştır.

Çalışmada Modern Çağda varlığını zayıflayarak sürdüren eski statüler ve kurumlar incelendikten sonra Modern Çağ içinde zayıflayan eski statüler, yeni doğan sosyal sınıflar ve bu çağın getirdiği yeni ekonomik düzen tartışılmıştır. Bu çalışma literatür-kaynak taramasına dayanan bir çalışmadır ve literatür taramasında kaynakların ana başlık ve alt başlıklar için referans olması amaçlanmıştır. Makalede öncelikle geleneksel statülerin oluşumu ve eski toplumların sosyo ekonomik düzeni incelenmiş, daha sonra modern çağın ekonomik temele dayanan sınıfların ve kurumların oluşumu ile yeni sınıfların ve ekonomik kurumların oluşturduğu yeni düzen araştırılmıştır. Bu çalışmanın amacı içinde; önceki çağlardan beri varlık gösteren eski sosyal statülerdeki ve ekonomik kurumlardaki güç kaybının nedenleri ile Modern Çağda güçlenen yeni ekonomik sınıfları ve bu sınıfların kontrolünde gelişen yeni ekonomik kurumları, sistematik devlet müdahaleciliğinin özelliklerini, Modern Çağın iktisat politikalarını tamamlayan ve devletçi politikalara meşruiyet sağlayan sömürgeciliği kapsayan bir araştırma olmak, Modern Çağ'ın ticari genişlemesinin sebepleri ve ticari genişleme içinde ortaya çıkan yeni düzeni açıklamaya çalışmak; bulunmaktadır.

\section{Modern Çağ İçinde Varlığını Zayıflayarak Sürdüren Eski Sosyal Statüler ve Kurumlar}

Orta Çağ bir gerileme ve duraklama çağıydı, Orta çağı bir önceki çağdan (antik çağ) farklı kılan değişim; sosyal, ekonomik ve toplumsal gerilemeyle ilgiliydi. Orta Çă̆'da ruhban sınıfının önemli ölçüde bir ekonomik belirleyiciliği vardı. Orta çağın ruhban sınıfının ve zayıf siyasal sistemi Feodalizmin yükselmesi, Merkezi Krallıklar kontrolündeki siyasetin gerilemesiyle ilgiliydi. "Zayıflayan merkezi krallıkların bulunduğu Feodal Avrupa'da, kilise güçlü bir kurum olarak ortaya çıktı, kilise, tüm sosyal sınıflardan insanlar üzerindeki etkisini arttırdı" (Orangefield Isd, s. 370). Merkezi krallıklar ellerindeki ekonomik ve askeri gücü prensliklerle paylaştıkça da Feodalizm güçlendi. Dolayısıyla bu çağda güçlü siyasi gelenekler, yerini dini geleneklere bıraktı ve kilise kendi geleneğini yarattı. Ancak Modern Çağ'ı farklı kılan değişim ise sosyal, ekonomik ve toplumsal ilerlemeyle ilgiliydi. Bu çağa yön veren unsurlar; ticari büyümenin güçlendirdiği tüccarlar ile Monarşilerin kontrolünde güçlenen siyasetti. Modern çağda büyüyen ticaret kiliseyi ve Feodalizmi besleyen bir kaynak değildi, bu nedenle dinin toplumsal etkisi, ruhban sınıfının ekonomik kontrolü ve Feodalizm zayıfladı. Modern çağda büyüyen ticaret tüccar burjuvaziyi ve Monarşileri besliyordu, ticaret büyüdükçe, eski sınıflar ve doğuştan gelen statüler zayıfladı, tüccar sınıfı güçlendi, merkezi devletler geliştiler ve iktisadi sorumluluk üstlendiler. Modern Çağ tam anlamıyla yeni bir çağdı ve ilerlemeyi temsil ediyordu. Dolayısıyla bu çağın ekonomik belirleyicileri, ekonomik ilişkileri daha önceki zamanlarla kıyaslanamayacak ölçüde toplumsal 
yapıyı etkileyebilecek güce sahipti ve iktisadi düşünce bu çağda daha somut ve daha bütünlüklü bir özellik kazandı.

16.yy. ekonomik hayatının doğurduğu şartlar orta çağ sınıfsal yapısını temelinden sarsıyordu. Sermayenin, pazarın ve rekabetin rolü gittikçe büyüyordu. Bu rolün 16.yy.dan daha sonraki dönemlere göre daha az önemli olduğu, doğru olmakla birlikte modern kapitalizmin bütün unsurları ortaya çıkmış bulunmaktaydı (Güriz, 1969, s. 80). Modern Çağ'ın ekonomik unsurları ya da sosyal statüleri orta çağdan farklıydı. Orta Çağ'da beliren ekonomik kurumlar büyük ölçüde geleneksel ve dinsel özellik taşıyorlard. Mesela serflik rejimi ile işletilen feodal mülkiyet, bir siyasal tercih olarak doğmuş ve veraset yoluyla devam eden geleneksel uygulamaya dönüşmüştü. Kilise ve ruhban sınıfi, statüsünü dinden alıyordu, dinsel özelliği olan bir mülkiyet ve kilisenin kontrolünde kalan bir servet vard1, dini gelenek bu servetin halkla paylaşılmasına izin vermiyordu. Ancak Modern Çağ'da bu geleneksel ve dini unsurlar varlığını sürdürmesine rağmen, güç kaybederek var oldular ve bir daha Orta Çağ'daki nüfuzlarına ulaşamadılar, ancak kamusal alanda zayıflayarak da olsa varlıklarını sürdürmeye devam ettiler. Modern Çağ'a hâkim yeni sosyal sınıfların ise bir ekonomik temeli vardı. Bu yeni ekonomik unsurlar ticaretle gelişen özel mülkiyet ve servet birikiminin yarattığı yeni sınıflardı.

16. yy. güçlü bir ticari ve ekonomik genişleme dönemiydi. Bu genişleme, Modern Çağın sosyal, politik ve kültürel diğer birçok dönüşümünde önemli rol oynadı. Merkantilistler, girişimciler ve bankerler sermayeyi hiç görülmemiş bir şekilde biriktirip manipüle etmişlerdi (Stearns vd., 2016). Gelişen ticaret, tarımdan ve sanayiden gelen kazançları geride bıraktı, özel mülkiyete dayanan ve daha güçlü ekonomik temele sahip bu sınıflar, ticaretten besleniyorlardı ve Orta Çağ'ın geleneksel statülerine hiç benzemiyorlardı. Büyüyen ticaret mülkiyetin el değiştirmesini sağlayarak, geleneğin ve dinin koruması altında olan eski statüleri, zayıflattı ve Modern Çağ'ın ekonomik ortamına uygun, Modern Çağ'ın kendi hâkim sınıfını yarattı. Ancak İslam ve Türk medeniyetleri dünya ticari sisteminin dışında olduklarından, Batı Avrupa'daki sınıfsal değişimle de karşılaşmadılar. Dolayısıyla İslam ve Türk toplumlarının sosyal yapısı Modern Çağda değişmedi. Bu çağ içindeki geleneksel statüler, çoğunlukla doğuştan kazanılan ekonomik ayrıcalıklarla varlığını sürdüren, böylece sınıfsal bir karakter kazanan toplumsal farklılıklardı. Bu statüler ve kurumlar; Orta çağ Batı Avrupa toplumuna özgüymüş gibi gözükse de benzer şekilde Avrupa dışındaki toplumlarda da geleneksel statüler ve geleneksel kurumlar mevcuttu ve ekonomik temelleri veraset yoluyla kazanılan ayricalıklı toprak mülkiyetine dayaniyordu.

\subsection{Ruhban Sinıfı}

Orta Çağ'da kesin bir toplumsal kural vardı, bir insan sınıfı içinde doğar ve genellikle tüm yaşamın sınıfı içinde yaşardı, çok çalışmak statüyü değiştirmezdi, hiyerarşi, soylular, şövalyeler, din adamları, tüccar ve köylüler şeklinde sıralanıyordu (Western Reserve Public Media, 2018). Bu sınıflar içinde bulunan ruhban sınıfı eskiden üst hiyerarşide sürdürdüğü varlığını Modern Çağ'da da zayıflayarak sürdürmüştür. Hıristiyanlık inancında başka bir dini görüş Protestanlık doğmuş, bu yeni görüş kendi kurumlarını ve cemaatini yaratmıştı. Dolayısıyla Modern Çağ' da Hıristiyanlık hem cemaat olarak hem de örgütsel olarak bölünmüştü

Luther Hıristiyanlığın örgütsel törensel yönlerini reddetmişti. Skolâstik felsefenin Hıristiyanlık üzerindeki etkisini de "papacıların bir sapması" olarak görmüştü, artık tanrı kilisenin törenlerinde, papazlarında ve kurumlarında aranmak yerine insanın içinde aranacaktı (Yıldırım, 2005, s. 4). Luther faiz ve adil fiyat konularında Orta Çağ'ın görüşlerini benimsemekle beraber, bu konudaki düzenlemeleri kiliseden ayırmış ve laik devletin düzenlemesine terk etmiştir. Luther ulusal devletin çıkarına bireyin çıkarlarından daha fazla değer verilmesini ve devletin ekonomi politikaları uygulamasının doğru olacağını savunmuştur (Savaş, 2000, s. 141). Böylece Avrupa'nın kuzey bölgelerinde yaşayan Hıristiyanlar Protestanlığın önermelerini kabul ederek bu yeni cemaate katılmışlardır. Modern Çăg'da Protestanlık, İskandinavya, Hollanda, Almanya'nın büyük bölümü, Fransa ve İsviçre'nin bir kısmı, Britanya ve İlanda'nın kuzey kısmına yayıldı. 
Aşağı yukarı Avrupa nüfusunun dörtte birini barındıran bu bölgelerde mülkiyet ve gelirde büyük bir artış meydana geldi. İngiltere'de manastırlar ilga edildi, bunlara ait binalar, toprak ve menkuller krallığın eline geçti, Krallıklar da bunların bir kısmını ya sattılar ya da kendi mülkiyetlerine kattılar. Hesaplandığına göre İngiliz milli servetinin üçte biri bu dönemde el değiştirmiş̧ir (Heaton, 2005, s. 196). Reform hareketi kilise yönetiminin toplum hayatındaki engelleyici ve baskıcı gücünün yıkılmasına yol açmıştı. Reform hareketi kilisenin politik gücünü azalttı ve kilise topraklarının dağıtılmasına neden oldu (Kılıç ve Demirçelik, 2011, s. 187). Modern Çağda kiliseler böyle bir süreç içinde bölündü ve Avrupa toplumu dinsel anlamda cemaatlere ayrıldı. Orta Çağ' da feodal toplumun bir parçası olan kilise ticaret çağında sahip olduğu toprak mülkiyetini büyük oranda kaybederek ekonomik gücünün yanı sıra toplumsal nüfuzunu da kaybetti. Sürecin sonunda Monarşiler güçlenerek kilisenin manevi tasarrufundan kurtulmuşlar ve kilisenin siyasal baskısını üzerinden atmışlardı. Modern Çağ'ın ticaretle gelişen ekonomik temele sahip olmayan her statü sınıfı gibi ruhban sınıfı da yeni ekonomik gelişmelerin yarattığı firtınada savruldular. Kilise ve ruhban sınıfı zayıflarken, dinin ekonomik etkinliği başka bir boyuta geçti. Protestan düşünceyi savunan Calvin modern kapitalizmin sözcüsü oldu, Calvin ticaret, kar ve faiz konusunda Protestanlığ kapitalizme destek çıkan, bir moral değer olarak yükseltti. Dolayısıyla din Modern Çağda piyasayla çatışan değil, piyasayla örtüşen bir ahlaki motivasyona dönüştü.

\subsection{Feodalizm}

Feodalizm; Modern Çağ'da gerileyerek varlığını sürdüren kurumlardan biridir. Feodalizmin, Modern Çağda askeri, siyasal, ve ekonomik nedenlerle geriledi. Orta çağda Feodal prenslikleri Monarşilere karşı koruyan surlar, Monarşilerin siyasal ve askeri bakımdan genişlemesini engelliyordu. Orta Çağ'da askeri teknolojinin yetersiz olması nedeniyle bu küçük krallıklar, merkezi krallıklar tarafindan zapt edilemiyordu. Ateşli toplar icat edildiğinde bu yeni silahlar prensleri koruyan kaleleri yıkmak için kullanıldı. Yeni askeri teknoloji Monarşilere avantaj kazandırdı, İstanbul un fethi sırasında test edilen ateşli toplarla birlikte, surların arkasında korunan küçük krallıklar zorla monarşilere katıldılar. Feodalizmin gerilemesinin siyasal nedeni ise tüccar burjuvazinin Monarşileri feodal prensliklere tercih etmesidir. Ticaretten zenginleşen yeni tüccar sınıfinın ihtiyaç duyduğu büyük piyasayı Monarşiler sağlayabilirdi, bu nedenle tüccarlar ve büyük kentler, Monarşiler için birleştiler, Monarşilerin siyaseten güçlenmesi Feodalizmi Modern Çağ'da siyaseten zayıflattı.

Feodalizmin gerilemesinin ekonomik nedeni ise kuşkusuz ticaretti. Kentlerin içinde doğan ticaret para ekonomisini geliştirdi ticari karları artırdı ve ticari karlardaki büyüme merkezi krallıkların vergi gelirlerini ve diğer ekonomik kaynaklarını geliştirdi. "Feodalizmin düşük emek üretkenliği, toprağın veriminin düşmesi, Lortların giderek büyüyen ihtiyaçlarının karşılanmamasına yol açtı. 14.yy.da ortaya çıkan veba salgını, nüfusun azalmasına ve işgücü kıtlığına neden oldu. Feodal gelirlerdeki azalma ve işgücü kıtlığı nedeniyle, Lortlar toprakları işletmek yerine kiraya vermeye başladılar. Parasal ekonominin gelişmesi ve ihtiyaçların piyasadan karşılanması, Serflerin yükümlülüğünü, para karşıllğı hizmet ilişkisine dönüşerek, bazı bölgelerde azalttı, bazı bölgelerde de daha da attırdı. Ürünü artırma yönündeki baskılar köylü isyanlarına ve feodal sistemin can damarının kesilmesine neden oldu... Bütün bu gelişmeler siyasal merkezileşme olgusunun yani merkezi krallıkların güçlenmesinin yolunu açtı" (Kaygalak, 2010, s. 190).

\subsection{Soyluluk ve Serflik Statüsü}

Modern Çağ' da toprağa bağlı soyluluk toprak aristokrasisi, Feodalitenin gerilemesiyle zayıflamıştır. Toprak aristokrasisinin dayandığı toprak mülkiyeti, Monarşilerin soy aristokrasisinin servetlerine katıldığından, toprak soyluları ekonomik olarak gerilemiştir. Ticari karların oluşturduğu büyük servetler tarımsal gelirleri aştığından, toprak aristokrasisinin üzerinde yükseldiği gelir kaynağı azaldıkça bu tür soyluluk gerilemiş̧tir. Ancak irsi bir temele dayanan soy aristokrasisi varlığını monarşilerin yükselmesine rağmen korumuştur. "Avrupa'daki her devlet, 
ayrıcalıkları yasalarla korunan bir soylu formunu kabul etmiştir” (Peter, 2016). Toprağın getirdiği katma değerin azalması soy aristokrasisini etkilememiş, onlar ticaretten gelen yeni kaynaklarla Modern Çağ'ın sonuna kadar varlığını sürdürmüștür. Soyluların pazara bağımlılığı, tüccarlarla iş birliğinin artmasına neden olmuştur. Soy aristokrasisi piyasaya baskı kurmak bir yana, Monarşik düzen içinde piyasayı geliştirerek piyasaya yardımcı olmuşlardır.

Zorunlu tarım işçiliği kurumu olan serflik, Orta Çağ Avrupa'sında yaygındır (Markevich ve Zhuravskaya, 2016, s. 2). Modern Çağda serflik feodalitenin gerilemesi ve toprak aristokrasisinin dağılmasından etkilenerek daha özgür bir statüye kavuşmuştur. Büyüyen kentler ve bu kentlerde parasal ekonominin gelişmesi, kırsal alandaki karşılıklı bağımlılığa dayanan sözleşmeleri ve ekonomik ilişkileri değiştirmiştir. Tarımsal ürünlerin katma değeri azalırken, 14.yy da ki veba salgınından dolayı ve büyüyen kentlerin sunduğu yeni iş alanlarının genişlemesi sonucu, şehirlere göç eden köylü nüfustan dolayı kırsal alanda nufus azalmış ve nüfus azlığı nedeniyle artan ücretler maliyetleri artmıştır. Emek kıtlı̆̆ ile maliyetler artarken ve tarımsal gelirlerin de azalması, nüfusun kentlere taşınmasına neden olmuş ve bu durum serflik rejiminin yumuşamasına yol açmıştır. Parasal ekonominin yaygınlaşması sonucu Lortlar zorunlu hizmet yükümlülüğünü kaldırdılar ve toprakları köylülere kiraladılar. Böylece köylüler kiracı ya da tarım işçisi durumuna geldiler. Ancak Modern Çağ'da büyüyen endüstrinin ve büyüyen kentlerin gida ihtiyacı hem sanayide hem de tarımda ucuz emeğe ihtiyacın artmasına neden oldu. Bu da emekçi sınıf üzerinde başka tür bir baskı doğurdu ve kölelik yeniden ortaya çıktı. Büyüyen uluslararası ticaret ve uluslararası rekabet nedeniyle ucuz emeğe duyulan ihtiyaç her zamankinden fazla oldu. Avrupalı tüccarlar mal sattıkları pazarlardan köle alarak, bunları Avrupa'ya taşıdılar ve yeni keşfedilen kıtadaki yerli halkı köleleştirdiler. Ticari genişleme içinde ekonomik faaliyetlerin ağırlığının kentlerde yoğunlaşması, yarı köle Serflik statüsünü zayıflatırken, tam kölelik statüsünü güçlendirdi, Afrika Modern Çağ'ın köle deposu oldu, Antik Çağ'dan sonra Modern Çağ' da köle ticareti yeniden doğdu.

\subsection{Loncalar ve Esnaflık Statüsü}

Ticaret ve paranın gücü, sanayi üretimini ve sanayi üretimi üzerindeki eski otoriteyi de değiştirdi. Sanayinin ihtiyaç duyduğu bol emek arzı, serflik sisteminden boşalan halkın şehirlere göçüyle sağlandı. Esnaflık sistemi büyük sanayinin rekabet gücüyle baş edemediği için, azalan iş hacmi ve iflaslar, esnafları güçlenen tüccarın karşısında geriletti. Loncaların mikro ölçekteki piyasa kontrolü ortadan kalkt1; sanayi üzerindeki yeni otorite ve kontrol, monarşiler tarafindan büyük ölçekte yapıldı.

Monarşiler ve kent devletleri, kendilerine gelir sağlayabilmek için kilisenin mallarının çoğunu, dinsel loncaların mallarını ve zanaat loncalarının dinsel amaçlar için bulundurdukları mallarını müsadere ettiler.... Piyasanın büyümesi nedeniyle "loncalar arasında gittikçe büyüyen bir farklı1ık belirmeye başladı. Bazı esnaf loncaları daha fazla sermaye ve daha fazla işgücüne sahip olmaya başladılar. Bir süre sonra loncalar ancak belli bir sermayeye sahip olanları, loncalara kabul etmeye başladılar. Bazı loncalar tekelleşti ve müşteriyi sömürmek yolunu tuttular. Diğer taraftan lonca mensuplarının çoğunluğu meydana gelen değişim yüzünden fakirleşmeye başladılar. Kendi geleneksel sanatları yanında, diğer işleri yaparak hayatlarını sürdürmeye çalıştılar (Kılıç ve Demirçelik, 2011, s. 187). Ticari sermaye, önce meta değişiminde aracılık rolündeydi. Daha sonra lonca kurallarına uygun olarak, küçük üreticiler katında, metalar biriktirmeye onlara hammaddeler sağlamaya, ödünçler verilmeye koyuldu. İşte küçük üreticilerin, tüccarların ekonomik bağımlılıkları altına girmeleri böyle oldu. Ticari sermayenin bunu izleyen faaliyeti, zanaatçıları; ücretli işçiler olarak çalışan durumuna getirdi (Aydemir ve Genç, 2011, s. 238).

\section{Modern Çă̆ İçinde Varlığını Güçlendirerek Sürdüren Yeni Sosyal Sınıf ve Kurumlar: Modern Çağın Yeni Ekonomik Düzeni}

Yaklaşık üç yüz yıllık tarih içinde kendisini gösteren ticari büyüme, ekonomik kazançları elinde toplayan kendi sınıfını, kendi kurumlarını ve kendi sosyo ekonomik ve politik düzenini 
yarattı. Ticaret üzerinden gelen yeni ekonomik gelişmenin yol açtığı ekonomik düzen ticari kapitalizm olarak kendisini gösterirken; kaynaklar devletin ve tüccar burjuvazinin kontrolüne geçtikçe yeni düzen bu ikisinin çıkarı doğrultusunda şekillendi.

\subsection{Modern Çağda Batının Devrimci Sınıfı Tüccar Burjuvazinin Yükselişinin Kısa Tarihi}

Modern Çăğ'ın en hızlı yükselen sınıfı tüccar sınıfıdır. Bu sınıf ekonomik temeli olan bir sosyal topluluk olduğu için ticari ekonominin büyümesiyle birlikte güçlenmeye devam etmiştir. Yeni üretim biçiminin ortaya çıkardığı değişime ayak uyduran bu sınıfi, tüccar kapitalist olarak tanımlamak, yaygın bir eğilimdir. Modern Çăg'ın tüccar kapitalisti ticaretten gelen servetlerle Modern Çağ boyunca ekonomik iktidara sahip oldu, zenginlik tüccar kapitalist sınıfın sosyal iktidarı kazanmasına yol açsa da, siyasal iktidara nüfuzu aynı ölçüde olmadı. Bu sınıfın devletle dayanışma içinde olmasına rağmen, siyasal iktidara nüfuzu hemen gerçekleşmedi. Tüccar burjuvazi ancak 1789 Fransız İhtilalıyla birlikte siyasal iktidarı kazanabilmiștir. Tüccar kapitalist sınıfın, zenginlik hırsı onun daha fazla güce sahip olmasını gerektirmekteydi. Zenginlik ancak tüccar kapitalist sınıfın kontrolündeki bir yapıda gelişebilirdi, dolayısıyla tüccarlar sonu gelmez taleplere sahiptiler. Devletin tanıdığı imtiyazlar, Modern Çağ'ın sunduğu zenginlik, Monarşilerin tanıdığı özgürlük, yeterli olmadı, her zaman daha fazlasını istediler, tüccarların artan taleplerinin karşılanması için gösterdikleri çaba onları Modern Çağın büyük devrimlerinin öncüsü yaptı. Yeni fikirlere yön verdiler, siyasal ve ekonomik devrimler bu sınıfın öncü rolüyle gerçekleşti. Tarihin hiçbir döneminde bu sınıfla boy ölçüşebilecek devrimci bir sınıf ortaya çıkmadı. 300 yıllık Modern Çağ' daki siyasal dönüşüm bu sınıfın eseridir. Monarşiler, kentlerin ve tüccarların destekleriyle ayakta kalabildiler ve Feodalizme böylece karşı koyabildiler. Modern Çağ boyunca destekledikleri Monarşileri daha sonra kendi elleriyle yıkan, bireylerin siyasete katılımı yoluyla hükümetleri belirlediği yeni siyasal sistemleri tüccarlar destekledi. Ticaret devrimi bu sinıfın ekonomik devrimi olduğu gibi, dünyayı etkileyen siyasal devrim, 1789 Fransız İhtilalı de bu sınıfın devrimidir, ticaret devrimi sonucunda ortaya çıkan, sanayi devrimi de bu sınıfın eseridir. Cumhuriyet rejimlerini savunarak bütün monarşileri yıkan ve milliyetçilik akımlarıyla cumhuriyetçiliği ve milliyetçiliği bütün dünyaya yayan ve yeni bir çağ açan da bu sınıftır.

Modern Çağ'da tüccar kesiminin yükselişi nasıl başladı. Kuşkusuz bu yükselişin itici gücü ticaretti. Bireysel olarak çalışan tüccarların iş akışlarını incelediğimizde, ticaret ağlarının 16. Yüzyıl içinde ne kadar karmaşık olduğunu görmekteyiz (Harreld, 2003, s. 13-14). 15. yy. sonunda ortaya çıkan büyük keşifler, uzak mesafeleri aşacak yeni deniz yollarına kapı araladı, 1487'de Portekizli Bartelmy Diaz, Ümit Burnu'nu dolaşt1, 1492'de Cenevizli Cristophe Colomb Amerika'yı keşfetti, 1498'de Vasga de Gama Ümit Burnu'ndan Hindistan'a vardı (Özgüven, 2001, s. 45)

Bat1 Avrupalılar; yeniden eski dünyayla ve ilk defa yenidünyayla deniz yolları üzerinden bağlantı kurarak dünyayla entegre oldular, Avrupa kıtası içinde ve dışında dünya piyasalarıyla iktisadi bütünlük sağladılar, daha sonraları sömürgecilik gibi devam eden gelişmelerle dünyanın geçirdiği bu değişimden daha fazla yararlandılar. İnsanoğlunun deniz üzerinden güvenli bir biçimde başka bir kıtaya ayak basması eski dünyayla (Asya) ve yeni dünyayla (Amerika) bağlantı kurması sadece bir ticari etki yaratmad1, bunun yanı sıra siyasal sistemler, toplumsal yapılar değişti ve bilimsel sanat edebiyat düşünceleri değişti (Rönesans, reform, kapitalist düşünce), teknoloji etkilendi ve büyük bir ticari patlama oldu. 15.yy.dan sonra büyüyen ticaret karşısında kilise de bu değişime direnmenin güçlügünü görmüştü. Bu nedenle de Kilise iktisadi doktrinini gözden geçirdi, Kilisenin yeni iktisadi doktrininin sözcüsü de Saint Thomas Aquinas oldu.

St. Thomas'ın görüşlerini bütünlüklü bir biçimde ele aldığımızda, onun 14.yy.da Katolik kilisesinin iktisadi görüşünü yeniden yorumlayarak çağın şartlarına uyum sağlamaya çalıştığını ve tüccara da zeytin dalı uzattığını kabul edebiliriz (Duran, 2012, s. 94-97). Saint Thomas Aquinos ilginç bir diyalogla ticaret üzerindeki kuşkuları dağıtmaya çalışmıştır. Yazdığı bu diyalogda Filozof bir tacire aldığı ürünleri, aynı fiyattan satıp satmayacağını sorar. Tacir satmak istemem diye cevap verir. Eğer böyle yapmış olsam benim katlandığım zahmetin karşılığı ne olur 
diye karşı soru sorar. Ancak satın aldığımdan daha yükseğe satarsam ailemi geçindirebilirim, diyerek diyalog devam eder. Aquinos bundan hareketle meşru sınırlar içinde ticareti kaçınılmaz görmüştür (Akalın, 2013, s. 273). En varlıklı zanaatkârlar arasından ticaretle uğraşan bir unsurun, üretimden kopup toptan ticaretin belirli bir alanını, tekeline alacak ticari örgütler kurulmasıyla, tüccar kapitalist sınıf görülmeye başlandı. Loncalar gerçekleştirdiği birleşmeler sonunda, mübadele koşullarını kendi lehine çevirebilecek tekel gücüne ulaştı. Çok dar sınırlara hapsolmuş pazarlarda aracılık rolü, hem kentteki zanaatkârın, hem de kırdaki köylü üreticinin ve aristokrat tüketicinin sömürülmesi yoluyla, tüccarın zenginlik ve birikimini arttırdı... Tüccar loncası ve kent yönetimlerinin, kentin çevresindeki ve kentteki ticarete yönelik düzenlemelerinin (devleti arkasına alarak) toptancı tüccarın çıkarını gözettiğine ilişkin pek çok kanıt bulunmaktadır...14. yy.da pek çok kentte tüccar sermayesinin gücü, yerel pazarlarda perakende ticareti sınırlayabilecek ve zanaatkârları dar bir tüccar birliğince bağımlı kılacak düzeydeydi (Kaygalak, 2010, s. 188-189).

Nitekim tüccarın ve kent yönetiminin gücünün artması Feodalizmin yönetim sınırını ihlal ediyordu. Feodal prensliklerin tüccar birliklerinin yönetime ve siyasal kararlara katılma isteklerine sırt çevirmeleri, tüccarın feodal düzenle çatışmaya girmesini gerektirmişti. 1789'a kadar tüccar sınıfı siyasal ve hukuksal eşitliği sağlayamasa da feodal prenslikler, kentlerden gelen vergi gelirlerinin düşmemesi bakımından tüccar birliklerini yok sayamadılar. Bunun sonucunda Modern Çağ boyunca tüccarın zenginliği artarken yönetime ve siyasal kararlara etki edebilme yeteneği de arttı. Esnaf loncaları, Feodalizm ve ruhban sınıfının gerilemesi Modern Çağ boyunca devam etse de, zenginliği kontrol eden burjuvazi hiç gerilemedi. Tüccar burjuvazi Modern Çağ'ın sonunda Fransız Devrimi'yle ruhban sınıfının ve soylu sınıfının üstünlüğünü kaldırarak siyasal ve hukuksal eşitliğe ulaştı, sermaye üzerindeki kontrolü ile tüccar kapitalist sınıf Modern Çağ'ın hâkim sınıfı haline geldi.

Burjuvazinin Fransız devrimine katılmasının nedeni diğer sınıflarla yaşadığı çatışmadır. Yukarıda da anlatıldığı gibi ticari burjuvazinin geçim kaynağı ticaretti, Feodal toprak düzeni ve kentlerdeki lonca sistemi ticaretin gelişmesinin önünde engeldi. Tüccarın devletle yakınlığına rağmen burjuvazi siyasal ve hukuksal anlamda soylularla eşit değildi. Tüccarın amaçlarına ulaşabilmesi ve bu sınıfsal çatışmadan kendini koruyabilmesi için, en azından siyasal ve hukuksal eşitliğe ihtiyacı vardı. Bu nedenle tüccar burjuvazisi, Fransız Devrimi'ne öncülük etmekten çekinmemiştir.

Fransız Devrimi aydınların da desteğini almıştır. Bu devrime özgürlüğü, kanunlar tarafından yasaklanmayanı yapmak olarak tanımlayan Montesquie, halk egemenliğini savunan J.J.Rousseau, insanların düşünce ve inançları açısından yargılanmamasını savunan Voltarie, destek vermiştir. Devrim'den sonra yayınlanan insan ve yurttaş hakları evrensel bildirgesinin 1. maddesinde, Her İnsan Özgür ve Haklar Bakımından Eşit Doğar, 6. maddesinde Herkes Kanun Önünde Eşittir Ve Yasa Tarafından Eşit Korunmaya Hakkı Vardır ve 17. maddesinde Mülkiyete Dokunulamaz Ve Kutsal Bir Hak Olduğundan Kamusal Zorunluluk Açıkça Gerekli Kılmadıkça Ve Bedeli Peşin Ödenmedikçe Kimse Bu Haktan Yoksun Bırakılamaz (Öndül, 1988, s. 688,692) ifadeleri yer almaktadır. Burjuvazi yalnızca soyluların iktidarını almamıştı, halkın ve aydınların da desteğini almıştı. Fransız devriminin insan ve yurttaş hakları evrensel beyannamesi, halka istediğini verdiği kadar burjuvaziye de istediğini vermiştir. İnsanlık tarihinde soylular ilk defa 18.yy.da eşit yurttaşlar oldular. İnsanlık tarihi ruhban ya da soylu sınıfın egemenliğine çokça şahit oldu, ancak halk egemenliği ilk defa kuruluyordu. İnsanlığın soylulara ve dini bürokrasiye karşı verdiği uzun mücadeleyi, burjuvazi kesin bir biçimde kazanmıştı.

\subsection{Modern Çağdaki Ticari Devrimin Ekonomik Kurumları}

Modern Çağ'ın ekonomik kurumları mülkiyet statüsü, girişim özgürlüğü, rekabet ve fiyat kurumu dini reform hareketinden çok şey kazanmıştır. Katolik inancı Modern Çağ'da etkinliğini sürdürse de ekonomik konulardaki görüsslerinin piyasada karşıllğı yoktu. Özel mülkiyet konusunda Modern Çağ piyasalarının, kar peşinde koşan hırslı tüccarların talepleri reformist 
hareket içinde yer alan, Calvin doktrini tarafından karşılanmıştır. Reform hareketinde özellikle de Calvin, özel mülkiyeti, girişim özgürlügünü savunmuş ve ticareti günahkârların işi olmaktan çıkarmıştır. Bu nedenle batı Avrupa toplumunun mülkiyet anlayışının reformist harekete paralel geliştiğini söylememiz mümkündür. Ancak Monarşiler siyasal alanda güçlendiklerinde, özgün iktisat politikaları da geliştirdiler. Monarşilerin iktisat politikası, bazen toplumsal anlayışın ve Calvinizmin karşısında olduğu gibi bazen de bunlara paraleldi. Bu nedenledir ki özel mülkiyet girişim özgürlüğü, rekabet ve fiyat kurumu tüccar dayanışmasını sağlamlaştıracak biçimde daha fazla Monarşiler tarafindan şekillendirildi.

\subsection{1. Özel Mülkiyet Statüsü}

Özel mülkiyet şahsi teşebbüse tanınan bir hak olup, piyasada üretim oluşumunun gerçekleşmesine hizmet eder. Piyasanın büyümesi ve küçülmesi özel mülkiyetin büyümesi ve küçülmesiyle doğrudan ilgilidir. Dolayısıyla piyasanın ölçeğini, özel mülkiyetin kısıtlanması ya da genişletilmesi belirler. Modern Çağ'da özel mülkiyet hukuki meşruiyet kazanmıştır. Reformistlerin mülkiyeti toplum yararına kullanılması idealini, Modern Çağ'ın Monarşik devletleri üstlenmiştir. Devletle dayanışma içinde olan tüccara mülkiyet konusunda ayrıcalık tanınması toplumun çıkarına uygun görülmüştür. Bu nedenle Monarşiler, ticari imtiyazlar tanıyarak, alım ve satım tekelleriyle tüccarlara ayrıcalıklar vermişlerdir. Modern Çağ' da özel mülkiyet hukuken tanınmasına rağmen, tam bir bireysel hak olarak korunmamış ve geniş kamu yararı yorumu nedeniyle, kamu müdahalesine her an açık olmuştur. Ancak buna rağmen diş ticarete dönük olarak kısmi kapitalizmin ilk oluşumunun gerçekleştiği bu çağda özel mülkiyet; tüccar ve kamu ayrıcalıkları dışında, bireysel bir hak olarak yeni güvenceler kazanmıştır.

$\mathrm{Bu}$ dönemin düşünce dünyasında özel mülkiyetin benimsenmesi, reformist din adamları sayesinde oldu. Modern Çağ' in mülkiyet teorisi büyük ölçüde Calvinist düşünceden etkilendi. Calvin, muhtemelen Cenevre gibi ticari bir şehirde yaşadığ 1 ve öğretisini benimseyenler arasında tüccarlar aktif bir grup olarak belirdikleri için, ticari faaliyeti olumlu ve faydalı karşılamak yolunu tutmuştur. Onun bu konudaki açıklamaları, ticari faaliyeti yararlı saydığını ve ticaret yoluyla elde edilen kazancı meşru olarak nitelendirdiğini göstermektedir. Calvin iş adamının kazancının toprak sahibinin kazancından daha fazla olmaması için bir sebep var mıdır, tüccarın kazancı da yalnızca onun sebat ve çalışkanlığından gelmez mi, diyerek ticari faaliyeti ve karı meşrulaştırmıştır (Güriz, 2011, s. 257). Calvin mülkiyetin tanrıya ait olduğu yolundaki teolojik kanıttan hareketle, özel mülkiyeti açıklamıştır. Calvine göre tanrı kendisine ait olan mülkiyeti, duyduğu sevgi dolayısıyla insana bağışlamıştır... Mülkiyet tanrı hibesi olduğundan, toplum yararına kullanılmalıdır... Calvin mülkiyetin şarta bağlı özelliğinden söz ederken, mülkiyetin kişiye çalışma borcu yüklediğini belirtmiştir. Malikin, mülk sahibi olduğu için, tembelliğe, israfa sapmamasını aksine mülk konusu olan şeyi değerlendirmek maksadıyla çalışması gerektiğini savunmuştur. Calvin'e göre Tanrının kendisine verdiği malları işlemeyen Tanrı önünde suçludur ve zengin bir tacirin faizle ödünç para alması ayıplanamaz (Güriz, 1969: 90-93).

Protestanlığın kurucusu olan Martin Luther (1483-1546) benzer şekilde toplumsal sınıflar arasındaki eşitsizliğin Tanrı'nın işi olduğunu ve bu yüzden de olduğu gibi korunması gerektiğini savunmaktaydı (Adaçay, 2012, s. 32). Modern Çağ'a baktığımız zaman özel mülkiyette tüccar burjuvazi elinde toplanan başka bir sınıfsal bir yoğunlaşma ve devlet mülkiyetinin varlığını görüyoruz. Toprakta mülkiyet soyluların ayrıcalığında devam ederken, ticaretten gelen kazançlar soylular dışındaki kişilerde tüccar burjuvazi elinde özel mülkü geliştirmiştir. Ticari kazançlardaki artış tarımın önemini azaltarak sanayi mülkiyetinin önemini arttırmıştır. Loncaların ve tüccar birliklerinin tekelci uygulamaları neticesinde, sanayi ve ticari faaliyetten kazanılan mülkiyetten, emekçi kesim çok az faydalanmıştır. Piyasa ekonomisinin önemli bir ekonomik kurumu özel mülkiyet, devlet mülkiyeti ile birlikte tüccar burjuvazi elinde toplanarak ve bir sınıf içinde yoğunlaşma göstererek başka bir sınıfsal karakter kazansa da, daha önceki zamanlara göre kısmen tabana yayılmıştır. 


\subsubsection{Girişim Ö̈gürlï̈̆̈̈̈}

Modern Çağ'da girişim özgürlüğü geniş bir biçimde kamu müdahalesine açıtı. Devlet ulusun çıkarını korumak için bu özgürlüğü sınırladı. Kamu girişimine ayrıcalıklar yaratıldığı gibi özel kişilere de ayrıcalıklar tanındı. Özel girişime; kamu girişimi ve imtiyaz verilen alanlar dışında; sınırlı bir özgürlük tanındı. Modern Çağ'da devlet eliyle bir piyasa yaratılmıştır, ancak bu piyasa serbest piyasa değil uydu bir piyasadır; yani devletin kontrol ettiği bir piyasadır. Loncalar ve tüccar birlikleri katı bir tutumla girişim özgürlüğünü kısıtlayarak karlarını korumak istemişlerdir. Dolayısıyla Modern Çağ'da girişim özgürlüğü kısmen söz konusudur, Loncalar, tüccar birlikleri ve devletin izin verdiği alanlarda kullanılmıştır.

\subsubsection{Rekabet Kurumu}

Modern Çağda dış piyasalarda kızışan rekabet nedeniyle, iç piyasalarda rekabet istenmemiştir. İç piyasada rekabetin kısıtlanmasının nedeni üreticilerin kendi aralarında rekabetinin ülkeye bir şey kazandırmayacağına inanılmasıdır. Modern zamanlarda iç rekabet üreticilerin birbirleriyle yarışarak güç kaybetmeleri anlamına gelmektedir. Ülkenin çıkarı üreticilerin çatışmasında değil dış piyasaya karşı dayanışmasında görülmüştür. Tüccarlar tekelci imtiyazlar verilerek desteklenmiş ve iç piyasalar rekabetin dışında tutulmuş ve tüccarlar birbirlerinin rakibi olmaktan çıkarılmıştır. Özellikle stratejik mallar ve dış ticaret için avantaj taşıyan sektörlerde rekabet yoktur, aksine ayrıcalık, imtiyaz ve tekel vardır. Dış rekabet gümrüklerle sınırlanmaktadır, devlet dış rekabete karşı ulusal firmaların yardımcısıdır; taşıma avantajları ve vergi avantajları ile dış rekabette tüccarlar devlet desteği aldığı gibi içerde de tüccarlar desteklenmekte, iç rekabet içinde onların kan kaybetmelerinin önüne geçilmektedir.

\subsubsection{Fiyat Kurumu}

Arz ve talep koşullarına bağlı olarak serbestçe oluşan fiyatlar, piyasanın ekonomik koordinasyonuna hizmet eder ve serbest piyasalarda fiyat, piyasanın sinyal aygitıdır ve ferdi teşebbüse yön verir. Modern Çağ'da fiyat piyasayı koordine eden bir müessese değildi, piyasayı devlet koordine etmekteydi, fiyatlar da devletin kontrol ve gözetimi altındaydı. Ulusun mallarının rekabet gücünün, fiyatların düşük olmasıyla artacağına inanıldığından devlet düşük fiyata ulaşmak için daha çok maliyetler üzerinde baskı kurmuştur.

\subsection{Ticari Devrimin En Etkili Ekonomik Kurumu: Sistematik Devlet Müdahaleciliğinin Özellikleri ve Sömürgecilik}

Modern Çağ bilinen ilk iktisat politikalarının uygulandığı çağdı. Bu çağın iktisat politikaları devletçi ya da devlet tarafından desteklenen politikalardı. Devletçi iktisat politikaları içerde piyasayı destekleyen dışarıda da ya korumacı ya da sömürgeci politikalardı.

\subsubsection{Devlet Müdahaleciliğ̈ine Giden Yol ve Sistematik Devlet Müdahaleciliğinin Özellikleri}

Modern Çağ tacirinin ekonomide yaptığını siyasal alana da taşıdığını görüyoruz. Tacirin Modern Çağ'da siyasal görüşlerinin temsilcileri N.Machievelli, J. Bodin ve T.Hobbes’tir. Bu üç düşünür, barış, huzur ve güvenlik adına Monarşiye (tüccarın çok yakından istediği siyasal rejim) sarılarak mutlak krallıkların siyasal teorisini kurmuşlardır. N.Machievelli Tanrı'yla siyasal iktidar arasındaki bağı kopararak bu dünyayı esas alan yaklaşım ortaya koymuş ve tüccarı devlete yakınlaştırmıştır. Hobbes; insanın kendi güvenliğinin sağlanması bakımından egemen güce ihtiyacı olduğunu ileri sürmüştü... Kişiler haklarını devlete güvenliklerinin sağlanması için devrettiğinden egemenliğin kaynağının toplum olduğunu ileri sürmüştür (Bulut, 2002, s. 24). Modern Çağ'ın siyasal teorileri; Feodalizmin ve kilisenin devlet üzerindeki vesayetini kaldırarak, devleti topluma dayandırmış hatta toplum üzerinde devlete vesayet tanımışlardır. Monarşilerin soylu ve ruhban sınıfına karşı kazandığı zaferin sürmesi, yeni ekonomik kaynaklara ve devleti destekleyecek güçlü bir sınıfin desteğine bağlıydı. Monarşiler; ruhban ve soylu sınıfın vesayetinden çıktıktan sonra, tüccar burjuvaziyle dayanışma gösterdiler. Tacirler monarşilerin ihtiyaç duyluğu parasal kaynaklara (yeni vergi) sahiptiler. Örneğin Macar kralı, 1501 yılında 
Türklere karşı, 4. Alexander komutasında bir birlik oluşturduğunda, Fugger ailesi (Güney Almanya'nın en nüfuzlu firmasının sahipleri) 40.000 ducatlık finansman desteği vermiş ve vaat ettiği yardımı düzenli bir şekilde ödeme sorumluluğunu üstlenmiştir (Akalın, 2006, s. 3). Bu nedenle Monarşiler, ruhban ve soylu sınıfı karşısına aldıktan sonra, tüccarların desteğiyle ayakta kalabilirdi, devletin vergiye ve parasal kaynaklara ihtiyacı vardı, bu kaynak da tüccar birliklerinde vardı. Tüccarın da, gümrüklerle bölünmüş piyasaların birleşmesine, imtiyazlara ve dış piyasalarda tüccarın güvenliğini sağlayacak, yeni pazarlar ve sömürgeler bulacak güçlü bir devlete ihtiyacı vardı. Tüccar burjuvazi için devletin önemi, devletin iktisat politikalarının tüccarın çıkarına uygun olmasıyla ilgiliydi. Modern Çağ' da devletin iktisadi görevi ticaretin artmasını sağlayacak, ticaret yanlı politikalardı. Ancak bu politikalar devletin tüccarını korumasını gerektirdiğinden müdahaleci iktisat politikaları olmaları gerekiyordu. Modern Çağ'da dine dayanan siyasal meşruiyet zayıflamaya başladığı için, Monarşiler kamu yararına dayanan yeni bir siyasal meşruiyet alanı açtılar.

Merkantilist hedefleri geçekleştirmek devletin iktisadi faaliyete büyük ölçüde müdahalesi anlamına gelmekteydi. Avrupalı devletler bu dönemde ithalat harcamalarını kısmak amacıyla ulusal düzeyde kendi kendine yeterliliği desteklemiş, dönemin hükümetleri de yerli girişimcileri güçlendirmeye ve korumaya çalışmışlardı (Barber, 1991, s. 19). Devletin koruyucu iktisat politikaları, toplumsal yararı ve dayanışmayı amaçlamıştı. Modern Çağ' da korunması gereken toplumsal dayanışma ve toplumsal yarar; ticaretin önündeki engellerin kaldırılmasını, devlet tarafından yol, köprü, limanlar inşa edilmesini, altyapının güçlendirilmesini, liman kentleri kurulmasını, iç gümrüklerin kaldırılmasını, hammadde ihracının sınırlandırılmasını, mamul mal ihracının teşvik edilmesini, mamul mal ithalatının sınırlandırılmasını, hammadde ithalinin teşvik edilmesini, hammadde ihracında avantaj sağlamak için maliyetlerin devlet kontrolünde düşürülmesini, ücret artışlarının baskılanmasını, faizlerin düşürülmesini, devletin örnek büyük sanayi işletmeleri kurmasını mümkün kılan, devlet müdahalelerini gerektiriyordu (Küçükkalay, 2008, s. 152).

Modern Çağda devletin piyasaya ihtiyacı vardır ve Modern Çağ'daki piyasa varlı̆̆ını devlete yani siyasete borçludur. Piyasayla devlet arasındaki dayanışma nedeniyle, devlet kendi yarattığ 1 eseri korumak, geliştirmek istemiş, ondan faydalanma hakkını, kimseyle paylaşmak istememiş ve piyasanın patronu olmuştur. Piyasa Modern Çă̆ devletlerinin en önemli finansal kaynağıydı, ticaret devletin aristokrasiye karşı ekonomik ve siyasal bağımsızlığını korumasına yardım ediyordu. Ticari vergiler monarşilerin en önemli gelir kaynağı olduğu için ekonomik ve siyasal bağımsızlık, piyasanın gelişmesine bağlıydı. Devlet bu bakımdan piyasayı himaye etmenin ötesine geçerek, piyasanın ta kendisi olmuş ve bu dönem piyasası tam anlamıyla devletin uydu piyasası olarak kurulmuştur. Modern zamanların başlarında ekonomik kazançların en büyük kaynağı dış ticaretti, çünkü altın kazançları dış ticaretten elde ediliyordu. Dış ticaretin ihtiyaç duyduğu dış pazarlar devlet sayesinde kazanılıyordu. Sömürgeler kazanmak, korumak için savaşmak gerekiyordu, dış rekabetin yaşandığı uluslararası piyasalarda tüccarı korumak, ticari yolların güvenliğini sağlamak, dahası dış rekabete karşı korunmak için de devlete ihtiyaç vardı. Dolayısıyla piyasanın ancak devlet desteğiyle gelişeceği inancı piyasayla devleti müttefik, tüccarlarla monarşiyi de ortak yapmıştır. Bu nedenlerle bu dönemin piyasasının devlet kontrolü piyasanın rızası hilafına değil aksine rızası hizasınadır. Modern zamanların iktisat politikaları belirgin bir biçimde devletçi politikalar olup piyasanın uymak zorunda olduğu kurallardı ve bu şekilde geliştirilen kurallara göre uygulanan sistematik devlet müdahaleciliği aşağıdaki özelliklere sahipti:

* Üretimin Rasyonelleşmesi: Modern Çağda eğitici ve disipline edici düzenleme ve çağrılarla üretim metotları geliştirildi. Orta Çağ' da mikro düzeydeki üretim kontrolü loncalarca mahalli piyasalarda yapıldığı gibi; ülke ölçeğinde ulusal piyasalarda bu kontrolü piyasanın hamiliğini devlet üstlendi. Küçük esnaf ve zanaatkârlar girişimci olmaları için eğitildiler. Kamu kesimi örnek işletmelerle özel kesime öncülük etti. Devlet işletmeleri ülkeye yeni endüstriler kazandırılmasında üretim ölçeğinin büyütülmesinde kullanıldı. Dıı̧ 
piyasalar için aracı şirketler kuruldu bunlar iç piyasadaki malları dış piyasalara ulaştırarak iç üretime pazar açtı.

* Genişletici Para Politikası: Modern Çağda para bolluğunun ticaretin gelişmesi ve finansmanı bakımından, gerekli olduğuna inanılıyordu (Biber, 2012, s. 111-112). Para politikasının belirleyicisi piyasa değil devletti. Bol para, kamu harcamaları ve sömürgelerde tüccarların çıkarlarını koruyan ordunun masraflarının karşılanması bakımından gerekliydi. Modern dönemlerde ekonomik ve siyasal nedenlerle para arzı artışı para politikasının temel amacı olmuştur.

* Ödemeler Bilançosu Fazlalılığı: Modern Çağ dönemlerinde iktisat politikalarının amaçlarından birisi ödemeler bilançosunda fazlalık yaratmak olmuştur. Ödemeler bilançosu fazlalılığının bütün ekonomik sorunları kendiliğinden çözeceğine inanıldığından, aşılması gereken iktisadi sorunun ödemeler bilançosunda fazlalık yaratarak çözüleceği kabul edilmiştir.

* Korumacılık: Ödemeler bilançosu fazlasına hizmet edeceği düşünüldüğünden bu dönemin karakteristik yapısında korumacı iktisat anlayışı görülmektedir. Dış ticaret kazançlarının korunması ve ülke sanayinin gümrük duvarlarının arkasında rekabetten etkilenmemesi ve gelişmesi için, iç piyasa diş gümrüklerle korundu.

* Piyasaya devlet Yardımı: Modern Çağ iktisat politikalarının özelliğinin yeni zenginlik anlayışına özgü müdahaleci iktisat politikaları olarak benimsendiğini söyleyebiliriz. Ekonominin en iyi kontrolünü ülke çapında örgütlü bir güç düzenleyebilirdi; devletin müdahale gerekçesi ulusun yararına dayandığı için, kamu yararı karşısında bireysel yararlar korunmamıştır. İleri düzeyde devlet müdahaleciliği Modern Çağ' da Monarşilerin belirgin karakteristiğidir. Modern Çağda altın biçimindeki servetin sömürgecilik ve ticaret dışından elde edilemeyeceğine inanılıyordu. Dış piyasalarda tüccarın ticari avantaj kazanması ucuz ve kaliteli mallar ihraç etmesiyle mümkündü. $O$ halde devlet ülke çapında en örgütlü güç olarak üretimin rasyonel örgütlenmesini sağlayabilir, maliyetleri düşürülebilir, üretimi organize ederek dış ticaret gelirlerini artırabilirdi. Devlet Modern Çağ' da piyasanın büyük ortağı olmuştur, özel kesim devlete tabi olmuştur. Güçlü devletin piyasa üzerindeki kontrolü imalat sanayinin desteklenmesinden, denetimine ve sömürgeciliğe kadar uzanan önemli boyutlara ulaştı. Devlet özel kesime yardım ederek ve devlete ait imalat endüstrileri kurarak, kredi desteği sağlayarak ve tekeller kurarak imalat sanayinin geliştirilmesini destekledi. Devlet ulusun ürettiği malların ucuz ve kaliteli olması için standartlar koyarak ve standartları kontrol ederek endüstriyi denetledi. Devlet, kamu işletmeleri ve izne bağlı özel işletmeler yaratarak, girişim alanını kendi gözetim ve denetiminde tutmuştur. Gelir yaratıcı özelliği olduğuna inanıldığı için büyük kamu harcamalarını da devlet üstlenmiştir. Sömürgeler tamamen ulusun çıkarına görüldüğ̈̈ için hükümetlerden sömürgeleri artırması beklenmiştir.

\subsubsection{Dış Ticareti Teşvik, Tekelcilik ve Sömürgecilik}

Modern Çağ'da iktisat politikalarının ana amacı para bolluğu sağlamaktı. Dış ticaret para stoklarını artıracak tek sektördü. Altın eğer içerdeki madenlerden karşılanmıyorsa ekonomik kalkınma için ticaretten başka çıkış yoktu. İhracat vergileri düşürüldü dış ticaret desteklendi, uluslararası piyasalarda rekabet gücünü artırmak için tüccarlara tekelci imtiyazlar, alma ve satma ayrıcalıkları verildi, böylece ülke sanayinin hammadde ve pazar ihtiyacını birden karşılayacak sömürgecilik, dönemin iktisat politikalarının temel özelliği oldu. Sömürgeler pazarlarda tekel hakkı kazandırıyordu; sanayinin ihtiyaç duyduğu hammadde ve mamul mallar için pazar garantisi sunuyordu; dolayısıyla ihracatla doğrudan ilgiliydi. Sömürgeler için savaşlar dahi göze alınabilirdi bunun için savaşlarda yapıldı. Bir ülke ana ülkenin mallarına talep yaratıyorsa piyasa oluşturuyorsa o ülke yararlı görüldü; sömürgeler tam bu özellikte ülkelerdi. İlk sömürgecilik dalgasının başladığı Modern Çağ'da az gelişmiş ülkelere ilginin artmasının nedeni buydu. Fakir ülkeler sömürgeye daha uygundu, çalıştıkça ana ülkeye talep yaratıyordu zengin ülkeler ise piyasalar için tehdit olarak görülüyordu zengin ülkeler çalıştıkça ana ülkeye rakip olduğundan 
sömürgeleştirilmeye ve ticari ilişki kurmaya uygun değillerdi. Sömürgeciliğin bir iktisat politikası olarak meşruiyeti ve ticaret çağında ekonomik tercihleri etkileyen bir kurum olarak yükselmesi Modern Çağın çarpıcı iktisat doktrini Merkantilizmin zenginlik inancına dayanır. Merkantilist doktrin zenginliği kıymetli madenle ölçen ve kıtlık sorununun çözümünü kıymetli maden artışına bağlayan, yalnızca kıymetli maden artışını sağlayacak politikaları benimseyen kısmi bir doktrindir. Dünyada kıymetli maden dünyadaki rezervler kadar sınırlı olduğundan bir ulusun altın biçimindeki servetle zenginleşmesi başka bir ulusun fakirleşmesi pahasına olabilirdi. Çünkü dünyadaki rezervler bir ulusun kontrolüne geçtikçe diğer uluslar fakirleşeceğinden ticaretten yalnızca tek taraf kazanabilirdi. Modern Çağın politika biliminin önemli düşünürü Niccolò di Bernardo dei Machiavelli'nin amaca ulaşmak için her yol mubahtır felsefesi gereği devletler kendi ulusunun çıkarı için dünyadaki sınırlı kaynakları ulus lehine kullanmak için başka ulusları sömürebilirdi. Devleti yönetenlerin; duygularına ya da inançlarına kapılmadan ve merhamet gibi insani duyguları bir kenara bırakarak; devleti yönetmesi gerektiği ve başarıya ulaşmak için her yola, her araca başvurulmasının mübah olduğunu savunan bu görüş, başkalarına ait olanın başkaları tarafından sahip olunması durumunu, yani sömürgeciliği ahlaki bir sorun olmaktan çıkarmış ve Modern Çağın kalkınma politikasının en önemli unsuru, en önemli müessesesi ve iktisat politikası haline gelmiştir.

\section{Sonuç}

Her ekonomik devrimden yeni bir sosyal yapı, yeni ekonomik ilişkiler ve ekonomik kurumlar doğmaktadır. Tarım devriminde tarımsal üretimin kesintiye uğramadan devam etmesi ihtiyacı, kendine özgü ekonomik kurumların gelişmesine ve yeni Sosyo-Ekonomik statülerin oluşmasına neden olmuştur. Bu dönem toplumlarında soylu ve ruhban sınıfinın kontrolü sayesinde tarımsal üretimin gerektirdiği devlet rolü ve dönemine göre üretimin yükünü taşıyan yarı özgür köylü serf ve köle, statüsü oluşmuştur. Ticaret devrimi; toplumların geçimini tarıma bağlı olmaktan çıkardığı için eski statüler ve devlet rolü değişime uğramış, yükselen yeni ekonomik faaliyetin gerektirdiği yeni sınıflar doğmuş, eski geleneksel statüler ve devlet rolü değişime uğramış ve yeni ekonomik kurumlar inşa edilmiştir. Ticaret çağında geleneksel statüleri gerileyerek, yerini ekonomik bir temel üzerinde yükselen ticaretten gelişen tüccar burjuvaziye bırakmışlardır. Tüccar burjuvazi; ticaretten elde ettiği büyük servetleri kullanarak eski dünyanın geleneksel sınıflarına ait olan ekonomik kontrolü eline geçirmiş, devletten yardım alarak zenginleşmiş, ekonomik imtiyazlar kazanmış ve Modern Çă̆'in ekonomik, siyasal ve sosyal iktidarına ortak olmuştur. Ticaret çağının ekonomik kurumları; tek yönlü ticareti ulus lehine sürdürmek için devlet ve tüccar ittifakı tarafından desteklenmiş; müdahaleci devlet içinde şekillenmiştir. Modern Çağ'ın devletçi piyasası içinde ulusun çıkarının bireysel çıkarların önünde tutulması, devlet tarafından ticaretin desteklenmesi, sömürgeciliğin devlet tarafindan yürütülen, tüccar tarafindan desteklenen bir iktisat politikası olarak sürdürülmesi, ekonomik hayatın bu şekilde akışına uygun olarak yeni ekonomik kurumların oluşmasına; neden olmuştur. Bunun yanı sıra tüccar burjuvazi sınıfının çıkarıyla devletin çıkarlarının uyuşması, eski dünyanın geleneksel statülerinin, soylu ve ruhban sınıfının devletle kurduğu ittifakından daha güçlüsünün, devletle tüccar burjuvazi arasında kurulmasına ve bu topluluğun sınıfsal ayrıcalıklar kazanmasına yol açmıştır.

$\mathrm{Bu}$ çalışmanın sonucu; Modern Çağ içindeki değişimi, coğrafi keşifler sonucu büyüyen ticaret ve sömürgeciliğin başlattığını, ticaretin kendi hakim sınıfını ve kendine uyum sağlayan yeni sosyal ve ekonomik düzeni yarattığını, devletin ve devletle dayanışma içinde olan tüccar sınıfının bu yeni düzeni kontrol ettiğini; ortaya koymaktadır.

\section{Kaynakça}

Adaçay, F. R. (2012). Modern İktisadi Düşüncenin Doğuşu, Merkantilizm ve Fizyokrasi, Ed,: B. Erdem ve H. İslatince, İktisadi Düşünceler Tarihi, s. 30-53.Ekin Yayınevi. 
Akalın, K. H. (2006). Orta Çağ İktisat Zihniyeti Sınırlarında M. Luther ve J. Calvin'in Tefecilik Yorumları, Çukurova Üniversitesi İktisadi ve İdari Bilimler Fakültesi Dergisi, 10(1), ss. 1-12.

Akalın, K. H. (2013). Orta Çağ İktisat Zihniyetinin Kazanç Maksatlı Ticaret Etkinliğine Karş1 Tutumu, Gümüşhane Üniversitesi Sosyal Bilimler Elektronik Dergisi, (7), ss. 254-280.

Aubin, H. Treasure, G. Salmon, J. Herrin, J. Champion, T. Peters, E. Herlihy ve D. Mayne, R. (2016). Nobles and Gentlemen, Encyclopædia Britannica, İnternet Adresi: https://www.britannica.com/topic/history-of-Europe/Nobles-and-gentlemen, E.T.: 7.6.2018.

Aydemir, G. ve Genç, S. (2011). Ortaçağın Sosyoekonomik Düzeni: Feodalizm, Elektronik Sosyal Bilimler Dergisi, 10(36), ss. 226-241.

Biber, A. E. (2012), Merkantilist İktisadi Düşünce, Ed.: M. Masca, O. Bahar, İktisadi Düşünce Tarihi, , s. 105-120, Lisans Yayınevi.

Bulut, N. (2002). Ortaçağdan Yeniçağa Geçiş Süreci Bağlamında Ekonomik Zihniyet Değişiminin Siyasal Düşünceye Etkisi, Erzincan Üniversitesi Hukuk Fakültesi Dergisi, 6(14), ss. 17-32.

Duran, B. (Ed.) (2012). Ortaçağda İslam Dünyası ve Batıda İktisadi Düşünce, Ed. M., Masca ve O. Bahar, İstanbul: Lisans Yayıncılık, ss. 61-102.

Güran, T. (1997). Ikktisat Tarihi, İstanbul: Acar Yayıncılık.

Güriz, A. (1969). Teorik Açıdan Mülkiyet Sorunu, Ankara: Ankara Üniversitesi Hukuk Fakültesi Yayınlar1.

Güriz, A. (2011). Hukuk Felsefesi, Ankara: Siyasal Kitabevi.

Harreld, D. J. (2006). Merchants and International Trade Networks in the Sixteen Century, Brigham Young University, XIV International Economic History Congress, Helsinki, İnternet Adresi: http://www.helsinki.fi/iehc2006/papers3/Harreld.pdf, E.T.: 8.6.2018.

Heaton, H. (2005). Avrupa İktisat Tarihi, Çev.: M. A. Kılıçbay ve O. Aydoğuş, Ankara: Paragraf Yayınevi.

Kaygalak, S. (2010). Kır Kent ve Kapitalizme Geçiş: Bursa Örneği, Mülkiye Dergisi, 31(257), ss. 185-203.

Kılıç, R. ve Demirçelik, M. (2011). Mülkiyet Kavramının Tarihsel Gelişimi Sürecinde Ortaçağ ve Reform Hareketi, Dumlupinar Üniversitesi Sosyal Bilimler Dergisi, (30), ss. 181-190.

Küçükkalay, A. M. (2008). İktisadi Düşünce Tarihi, İstanbul: Beta Basım Yayım.

Markevich, A. ve Zhuravskaya, E. (2016). The Economic Effects of the Abolition of Serfdom: Evidence from Russian Empire, Internet Adresi: http://piketty.pse.ens.fr/files/MarkevitchZhuravskaya2016.pdf, E.T.: 7.6.2018.

Orangefield Isd; European Middle Ages, 500-1200, İnternet Adresi: http://www.orangefieldisd.com/view/14314.pdf, E.T.: 22.5.2018.

Öndül, H. (1988). 1789 Fransız Devrimi ve Etkileri, Ankara Barosu Dergisi, (4), ss. 688-692.

Özgüven, A. (2001). İktisadi Düşünceler - Doktrinler ve Teoriler, İstanbul: Filiz Kitabevi.

Savaş, V. (2000). Iktisadın Tarihi, Ankara: Siyasal Kitabevi.

Small, G. (2005). A Christian Understanding of Property: Spiritual Themes Underlying Western Property, University of Technology, Sydney, İnternet Adresi: http://www.prres.net/papers/Small_A_Christian_Understanding_Of_Property.Pdf, $\quad$ E.T.: 7.6.2018. 
Stearns, P., David H., Aubin, H., Barzun, J., Champion, T., Herrın, J., Frasetto, M., Parker, G., Salmon, H., Herlihy, D., Mayne, R., Peters, E., Treasure, G., Sorensen, M. ve Weinstein, D., (2016), The Emergence of Modern Europe, 1500-1648, Economy and Society, Encyclopædia Britannica, İnternet Adresi: https://www.britannica.com/topic/history-of-Europe/Theemergence-of-modern-Europe-1500-1648, E. T.: 24.5.2018.

Torun, İ. (2003). Endüstri Toplumunun Oluşmasında İktisadi ve Sina-i Faktörler, C. ̈̈. İktisadi ve İdari Bilimler Dergisi, 4. (1), ss 181-196.

Trethewey, R. (1974). The Establishmentof Serfdom in Eastern Europe and Russia, The American Economist, Vol 18, Issue 1, pp. 36-41, İnternet Adresi: https://doi/10.1177/056943457401800106, E.T.: 7.6.2018.

Western Reserve Public Media; The Middle Ages, İnternet Adresi: https://westernreservepublicmedia.org/middleages/feud_clergy.htm, E.T.: 31.5.2018.

Yıldırım, E. (2005). Toplumsal Gelişme Açısından Protestanlık ve İslam, Dumlupınar Üniversitesi Sosyal Bilimler Dergisi, (12), ss. 51-64.

\section{ETIKK ve BİLIMSEL İLKELER SORUMLULUK BEYANI}

$\mathrm{Bu}$ çalışmanın tüm hazırlanma süreçlerinde etik kurallara ve bilimsel atıf gösterme ilkelerine riayet edildiğini yazar(lar) beyan eder. Aksi bir durumun tespiti halinde Afyon Kocatepe Üniversitesi Sosyal Bilimler Dergisi'nin hiçbir sorumluluğu olmayıp, tüm sorumluluk makale yazarlarına aittir. 